\title{
The Reflections of the English Language Teaching Department Students on Internship Programs: A Case of Erbil
}

\author{
Ali Bala ${ }^{1} \&$ Emine Bala ${ }^{1}$ \\ ${ }^{1}$ Tishk International University, Education Faculty, English Language Teaching Department, Iraq (KRG) \\ Correspondence: Ali Bala, Tishk International University, Education Faculty, English Language Teaching \\ Department, Iraq (KRG). E-mail: ali.bala@tiu.edu.iq
}

Received: September 7, 2020

Accepted: October 10, $2020 \quad$ Online Published: October 28, 2020

doi:10.5539/ijel.v10n6p372

URL: https://doi.org/10.5539/ijel.v10n6p372

\begin{abstract}
Practice teaching for pre-service teachers is a crucial affair before starting their carrier. It is considered one of the fundamental elements of whole teaching programs of education faculties since the teacher candidates find the opportunities to observe and practice their theoretical knowledge through practice teaching programs in schools. Within this context, the present research sought to reveal the reflections of the education faculty's seniors on practice teaching course utilizing both qualitative and quantitative methods. A private university's English Language Teaching department's seniors in Erbil were selected by convenience sampling as research sample, and 31 students participated in the questionnaire. A semi-structured survey used for this study including the parts of demographics, knowledge, skills and dispositions, field experiences and practice teaching, quality of instruction and two open-ended questions. The results indicated that most of the students expressed their positive reflections on their internship program. They believe the internship programs enable them to enhance their teaching skills and prepare them for real classroom atmosphere before graduation.
\end{abstract}

Keywords: English Language Teaching, internship program, practice teaching, pre-service teachers

\section{Introduction}

"I hear and I forget. I see and I believe. I do and I understand."

- Confucius

The Russian psychologist Vygotsky propounded the sociocultural theory of development which signifies the effect of language, social interaction, and culture on the learner's developing intellect. According to him, cognitive development appears when the learner interacts with the adults - more knowledgeable ones such as parents, teachers, or other adults - and thus the learner may obtain the skills and knowledge. The more experienced adults assess the learner's preparedness for the new tasks, and if needed they supply further assistance to help them acquire advanced knowledge and skills with intense usage of language and social interaction. Vygotsky proclaims the social interaction is the fundamental component for the development since he believes the learner cannot acquire the needed skills and knowledge on his own (Eggen \& Kauchak, 2007).

Church (2017) states that education and its functions have evolved in time firstly, it was accepted as child care which was assisting the families busy in fields, later on, it was seen as a process to building up capability, and providing skills that would facilitate the later life of the children finally it transformed to the process to prepare children for the competitive nature to become a workforce. This transformation can also be divided into three main stages as:

- Education 1.0 I'll deliver content at my pace and in my way and you will learn if you can.

- $\quad$ Education 2.0 I'll adjust how and what I teach so that it gives you the best chance for success.

- Education 3.0 I'll provide you with the resources and content you need so you can learn what you need, in a way that works for you, whenever and wherever you are. I will then make myself available to help you apply that learning in a useful manner.

Furthermore, two important points are indicated in Smith's (2018) study that is teaching should contain: a) setting out with the intention of someone learning something and b) considering people's feelings, experiences, and needs. Teaching is only teaching if people can take on what is taught. 
In this context, the practical side of teacher education has significant importance for the quality of education. Most of the universities are offering practice teaching programs for their senior students in education faculties to provide real-life experience and give them chance to turn their theoretical information into practice in advance. The practice teaching program assists the trainees to obtain and progress purposeful and scientific experiences. These programs help pre-service teachers to emerge their full potential and will equip them to act their future role as a teacher with a lot of attention (Wambugu, Barmao, \& Ng'eno, 2013).

In this research, a private university's English Language Teaching department senior students' internship program was analyzed to reveal the reflection of the students about their practice teaching experience in governmental and private schools. The students choose their practice schools and mentor teachers through their personal connection or the help of department instructors. Then, the faculty approves their schools, assigns a supervisor for each, and sends an informative letter to the school principals to provide information about the purpose of the internship program and the tasks that the students are responsible for during the semester. Within the scope of the internship program, the seniors must spend six hours a week in their internship schools. In the first term, they spend their time mainly observing the mentor teachers' classes, yet less experiencing practice and assisting them to prepare classroom materials or exam checking. In the second term, the teaching amount should be equal to observing at least; that is, they are supposed to teach four hours a week. At the end of each internship day, they should type observing reports for each class to university supervisors based on their observation including mentor teacher's methodology, teaching techniques, classroom management skills, teaching material, learner types, etc. In addition to this, the pre-service teachers should also submit attendance sheets to university supervisors on a weekly basis. Based on these attendance reports, most of the student teachers spend more time in their practice schools than required.

\section{Research Questions}

The present research sought to find the answers to the following questions:

1) Do the pre-service teachers believe their internship program contribute to enhance their teaching and learning knowledge and skills?

2) Do the pre-service teachers find opportunities to employ their skills and knowledge?

3) What do the pre-service teachers think about the quality of instruction of the supervisor?

4) What are the major strengths and weaknesses of the program and practical solutions from pre-service teachers?

\section{Literature Review}

The change continuously takes place in education and it brings new understandings, conceptions, interpretations, and strategies that lead innovation. If you are a student, a teacher, a parent, an administrator, or a decision-maker, if you're involved in education in any way, you can be part of that change. Three forms of understanding are required to do this: a criticism of how things are, a vision of how they should be, a principle of change, or how to shift from one to another (Robinson, 2015).

In order to achieve quality education, it is necessary to identify the central role played by teachers in their classrooms. Classroom teachers play a significant role in determining the achievements of quality education success and failure. What teachers know and willing to do in the classroom are significant factors that determine the success of student learning. In time as the teaching act has become more complex and highly skilled educator must be able to apply different practices for many different purposes, integrate and implement different types of expertise, develop a comprehensive pedagogical vocabulary and respond to the variety of learners in the classroom. When we observe teachers and learners in action what we see is not the mechanical application of methods and techniques, but rather a reflection of how teachers interpreted these things (Fhaeizdhyall, 2008).

Universities should design the internship programs for the student teachers that they are able to apply their theoretical knowledge into practice with guidance, support, and responsibility in addition to the theoretical courses that teach solely theory and techniques. It is a necessity that the internship program should be designed in a way that boosts the student teachers' experience level, teaching performance, strategies and abilities, and problem-solving skills (Darling-Hammond, 1990)

Kovacs (2017) calls this program a learner-to environment relationship that, once learned and related to previous learning, creates a new understanding outcome. This new learning evolves into a transition in perception, emotion or behavior. According to him, today, the teachers should be faster than ever to acquire new skills and knowledge to provide efficient classroom learning. Furthermore, 21st-century teacher training is no longer an 
option but a kind of moral obligation that comes with the career, and to be able to carry out their jobs, teachers need to know how to work with others.

The notion of teaching practice is grounded in experiential learning inspired by Dewey, and Vygotsky's social cognitive theory and situated learning (Kiggundu \& Nayimuli, 2009). Practice teaching offers training for student teachers in the real environment of teaching and learning. A student teacher is given the opportunity to learn the art of teaching during the teaching practice before entering the real world of the teaching profession.

One of the most important components of the practice teaching program is mentor teachers. Mentoring is often conceived as the individualized support, assistance, guidance, and challenge given to a teacher with little or no experience by one more experienced teacher. Mentors are believed to promote and ensure the professional development of promising candidates in modern times. It was stated that student teachers identify with their cooperating teachers more than with their teacher trainers or with other college personnel (Rajuan, 2008). It is obvious that because of the pre-service teachers' mentoring experience, student teachers are cognitively and affectively changed (Hawkey, 1997).

A qualified generation will be available only through qualified teachers. Therefore, it is important to investigate the professional concerns that affect the qualifications of pre-service teachers' who are educated in faculties (Karakaya, Avgın, Gömlek, \& Balık, 2017). Quick and Siebörger (2005) conducted specific questions through a survey on whether there should be school-based experience or less than the students currently had. Most survey responses felt it was necessary for student teachers to spend more time in schools. It was found out that pre-service teacher training programs cannot be complete without an effective practicum program where student teachers' go to the field and face the various classroom-related situations and taking responsibility for each one of them (Wambugu et al., 2013).

\section{Methodology}

The aim of this research is to evaluate the reflections of pre-service teachers towards practice teaching program. The Convergent Parallel Design among mixed-method research designs was applied in which 'the researcher concurrently conducts the quantitative and qualitative elements in the same phase of the research process, weighs the methods equally, analyzes the two components independently, and interprets the results together' (Demir \& Pismek, 2018, p. 123). A Likert style rating scale was utilized to assess the responses in the quantitative section. Williams-Pettway's (2005) Survey of Teacher Education Programs (STEP) was adapted and used for this study including the parts of:

- Demographic,

- Knowledge, Skills and Dispositions,

- Field Experiences and Practice Teaching,

- Quality of Instruction,

- Two Open-ended Questions (see Appendix B).

\subsection{Participants}

A private university's English Language Teaching (ELT) department's pre-service teachers in Erbil comprised of the research sample and 31 of the entire population of the ELT department's seniors involved in this study. They do their internship in both governmental and private schools. In the first term of the academic year, the students take practice teaching course which is mostly based on observing the mentor teachers at schools, helping them class material preparation and doing the tasks given by university supervisors, and in the second term they take school experience which includes teaching in the real class, observing the mentor teachers, doing the tasks given by the supervisors.

\subsection{Data Collection and Analysis Procedure}

The survey was distributed to ELT department seniors in the classroom before two weeks from the finals so that they could have enough experience to give a reflection on the questions more accurately. And the results except the last two open-ended questions were filtered and analyzed through SPSS data editor. The last open-ended questions were interpreted based on the coding system created by the researchers.

\section{Results and Discussion}

Among the total participants $(\mathrm{n}=31), 61 \%$ of them is female $(\mathrm{n}=19)$ and $39 \%$ is male $(\mathrm{n}=12)$. All female students do their internship in primary schools. Based on their internship school preferences at the beginning of the year, most of the female students express to the university supervisors they believe dealing with primary 
school students is easier than the others, so they prefer to do their internship in primary schools. $32 \%$ of male students selected secondary school and $6 \%$ of them chose a high school for their internship. The preference of the school type as private (52\%) and governmental (48\%) is equal (see Appendix A).

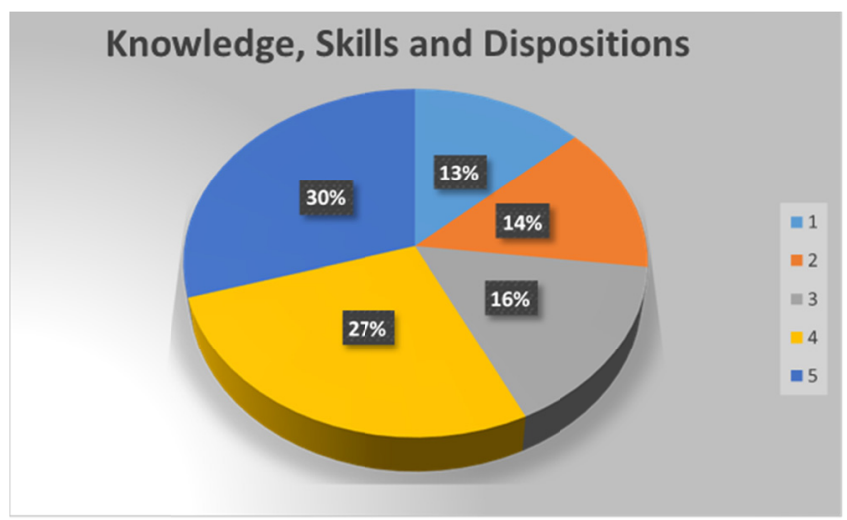

Figure 1. Student teachers' perceptions on their knowledge, skills and disposition improvement during practice teaching

Figure 1 illustrates student teachers' perceptions of their knowledge, skills, and disposition improvement during practice teaching experience at schools. $57 \%$ of them believe the internship program provides a good foundation in ELT, helps them understand different language levels and learning styles of students, and enhances their critical thinking and problem-solving skills in a teaching context. Additionally, they think this program helps them learn a variety of teaching strategies and how to adjust teaching methods in a lesson in addition to assessment techniques and how to use them effectively and teaching how to evaluate the effectiveness of their teaching. In contrast, $27 \%$ of the students do not believe their knowledge, skills and disposition improvement does not exist as an outcome of this program (see Appendix A).

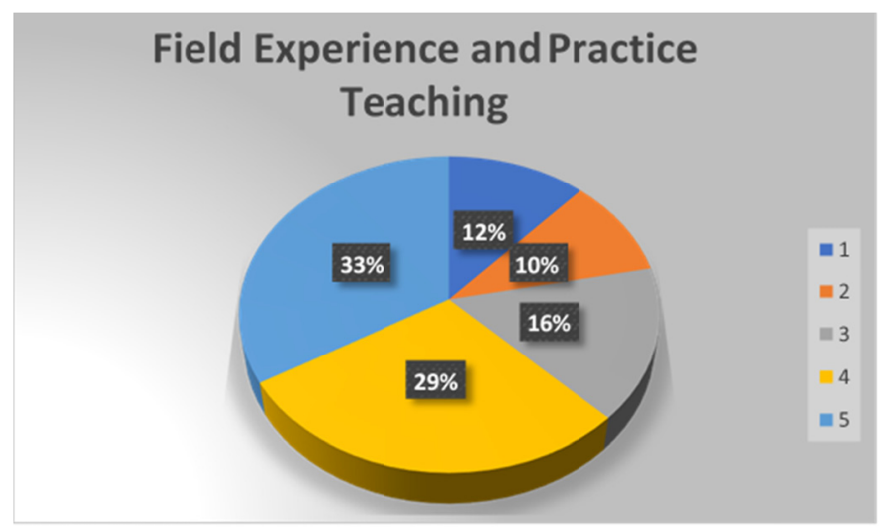

Figure 2. Student teachers' perceptions on field experience and practice teaching

Figure 2 represents the students' perceptions of their field experience and practice teaching performance during their internship program. $62 \%$ of the students claimed that the internship program provided valuable opportunity to employ their knowledge, skills, and dispositions and ensured them to experience different grade level students with various characters. They also think that this program helped them to develop their competencies for their teaching career by providing effective, and continuous mentorship and supervision on teaching methods, using technology, dealing with different learner types, etc. Provided feedback and suggestions also contributed to their teaching skills improvement. On contrary, $26 \%$ of the pre-service teachers believe that this program did not have any significant effect on their teaching skills development, or they could not get effective mentorship or supervision at the intended level (see Appendix A). 


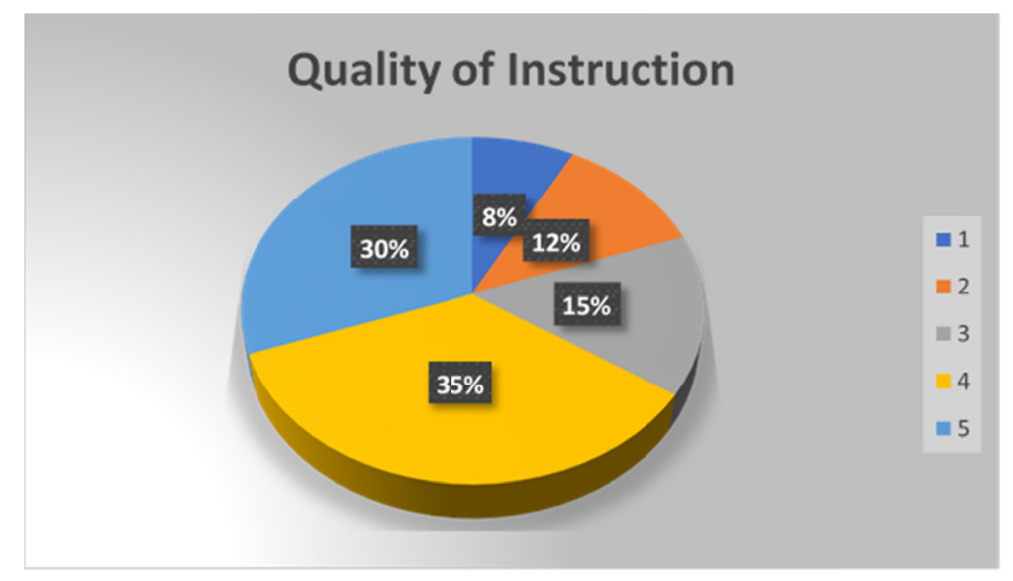

Figure 3. Student teachers' perceptions on quality of instruction

Figure 3 shows the perception of the pre-service teachers on the quality of education. The majority of the students $(65 \%)$ assert that appropriate instructional material utilized, and multiple teaching strategies are applied enthusiastically to help them learn during the internship. Although the limited number of the students expressed drawbacks in terms of communication, in fact, most of them were satisfied with the attitude of mentors and supervisors' respectful communication manners (see Appendix A).

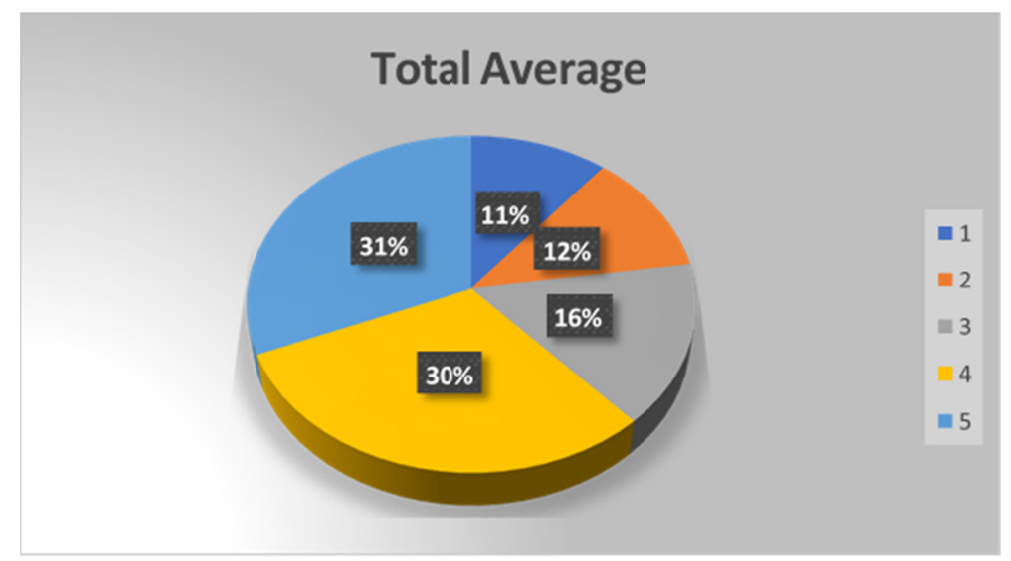

Figure 4. Total average of the reflections on the program

As seen in Figure 4, $61 \%$ of the teacher candidates show satisfaction in general whereas $23 \%$ of them reveal negative insights which of the reasons are indicated in the open-ended questions part. In total the overall, $16 \%$ of them are undecided since the students might not have understood the survey questions, or they might not have encountered the situations in the questions according to the researchers' perspectives (see Appendix A).

\subsection{Reflections of the Pre-Service Teachers on Strengths and/or Weaknesses of the Internship Program}

In the qualitative part of the survey, two open-ended questions were asked to the participants as follows;

1) Identify three major strengths and/or weaknesses of your practice teaching program.

2) Suggest two or more ways to strengthen your practice teaching program.

Based on the frequent responses of the attendees, it could be concluded that pre-service teachers see the mentor teachers' assistance and guidance as the main strength of the program. As Vygotsky's Social Construction theory claims, scaffolding from more experienced one contributes to inexperienced one (Nyikos \& Hashimoto, 1997). From this perspective, they think that continuous interaction with supervisors and mentor teachers helped them to improve their learning skills and teaching capacity. Error correction of the mentor teachers provided them valuable feedback to see their mistakes. 
Furthermore, pre-service teachers are supposed to carefully observe the classroom to raise their awareness of teaching strategies, student-teacher interaction, teaching materials, and learner types in the classroom and preparing a report on previously set tasks. Most of the participants reflected that these tasks had positive effects on them since real-life experience encouraged them for teaching. Besides that, they learned various teaching techniques, and how to use teaching materials effectively. They are also able to distinguish the English level variety of the students and learner types tendencies such as, visual, auditory, kinesthetic.

Moreover, student teachers indicated this program enhanced their capability to design creative lesson plans in addition to time management. They analyze the mentor teachers' lesson plans to see and understand the components of the plan. Then, they assess whether the parts are smoothly processing or not, so they gain some knowledge to create their further plans.

One of the fundamental factors affecting student learning is a teacher's classroom management skill. Especially the novice teachers conceive the classroom management issue as a constant matter. The more the classroom components equip with technology, the more highly skilled teachers in classroom management are demanded (Evertson, 1995). In this research, the improvement of teaching and classroom management skills is considered as one of the major benefits of the program by most of the students. They indicated that they learnt numerous ways from their mentor teachers to create a positive relationship with students without violating positive teaching and learning atmosphere.

On the other hand, some of the students have some negative implications on the limited technological equipment, overcrowded classes, and low language level in governmental schools. Almost all the students who do their internship in governmental schools complain about the classrooms' crowdedness which hinders effective teaching implementation. Another one is the governmental schools do not provide enough technological facilities for the pre-service teachers to apply technology-required classroom activities which encourage students to engage in the learning process. The last complaint was the low English level of the students in governmental schools. Pre-service teachers think that they cannot use their teaching skills efficiently due to the lack of language level of the classroom.

\subsection{Suggestions from the Pre-Service Teachers}

Teacher students expressed their suggestions to improve the practice teaching program to be more effective and beneficial for their future careers. Firstly, most of the students indicate that practice teaching time is not enough, and it should be extended to provide more teaching opportunities in a real classroom atmosphere. Secondly, trainees demand additional support from mentor teachers or supervisors for preparing lesson plans more effectively with creative ideas. They feel that they need more practice and assistance on this issue. Thirdly, they expressed that, the number of tasks should be decreased, and clearer instruction for the task should be provided by the supervisors to avoid ambiguities. Additionally, the observation reports should be submitted on a weekly based instead of daily because it brings a heavy workload and shortage of time for trainees. Finally, they assert that communication channels should be improved with mentor teachers in order to share some ideas about the students and course content based on their observations. Some of the trainees hesitate to share their thoughts, reflections and make comments on mentor teachers' courses due to the worries about mentor teachers' assessment might affect their passing grade or some other problems might occur.

\section{Limitations of the Research}

The research sample is one of the limitations of this research because it was conducted just in one private university in Erbil, so the results cannot be generalized to the entire population of the English Language Teaching department. Another limitation is that the research does not include governmental universities; the data collected from state universities could change the results.

\section{Conclusion}

The result of the research study shows that the internship program of the private university where the study conducted contributes to students' language development and helps them to improve their language level. The majority of the students believe that the internship process helped them to improve their language skills in terms of use of language and understanding spoken language at various levels with different accents. In addition to this, results explicitly reveal that this program raises students' awareness about teaching strategies to teach to the diverse students at different levels and learning styles (Akiba, 2011). The performance of mentor teachers and supervisors has a significant role in the development of trainees. They provide a role model to the trainees in issues such as classroom management strategies and teaching techniques (Nyikos \& Hashimoto, 1997). The quality of the communication between mentor teachers and trainees could be consolidated. During this program, 
trainees have a chance to observe and apply the theoretical information that they acquire at the university in the real classroom atmosphere.

\section{Recommendations}

In view of the conclusion, the following recommendations could be made;

1) A comparative study could be done next year to understand the change in the perceptions of the pre-service teachers.

2) A further data analysis could be conducted to reveal the perceptional differences in governmental and private schools.

\section{References}

Akiba, M. (2011). Identifying program characteristics for preparing pre-service teachers for diversity. Teachers College Record, 113(3), 658-697.

Church, M. (2017). Education 3.0. In C. Matt (Ed.), Next: Thoughts About Tomorrow You Can Talk About Today (pp. 98-107). USA.

Darling-Hammond, L. (1990). The Teaching Internship. Practical Preparation for a Licensed Profession. The Rand Corporation, 1700 Main St., PO Box 2138, Santa Monica, CA 90406-2138.

Demir, S. B., \& Pismek, N. (2018). A Convergent Parallel Mixed-Methods Study of Controversial Issues in Social Studies Classes: A Clash of Ideologies. Educational Sciences: Theory and Practice, 18(1), 119-149.

Eggen, P. D., \& Kauchak, D. P. (2007). Educational psychology: Windows on classrooms. Prentice hall.

Evertson, C. M. (1995). Classroom Organization and Management Program. Revalidation Submission to the Program Effectiveness Panel, US Department of Education.

Fhaeizdhyall, A. (2018). The Effectiveness of Teacher Education Program: Identifying the Difficulties and Challenges Faced by the Pre-Service English Teachers. International Journal of English Language Teaching, 6(1), 1-17.

Hawkey, K. (1997). Roles, responsibilities and relationships in mentoring: A literature review and agenda for research. Journal of Teacher Education, 48(5), 325-336. https://doi.org/10.1177/0022487197048005002

Karakaya, F., Avgın, S. S., Gömlek, E., \& Balık, M. (2017). Examination of Pre-Service Teachers' Anxiety Levels about Teaching Profession. International Online Journal of Education and Teaching, 4(2), 162-172.

Kiggundu, E. M., \& Nayimuli, S. T. (2009). Teaching practice: a make or break phase for student teachers. South African Journal of Education, 29(3). https://doi.org/10.15700/saje.v29n3a129

Kovacs, H. (2017). Learning and teaching in innovation: Why it is important for education in 21 st century. Neveléstudomány, 5, 45-60. https://doi.org/10.21549/NTNY.18.2017.2.4

Nyikos, M., \& Hashimoto, R. (1997). Constructivist theory applied to collaborative learning in teacher education: In search of ZPD. The Modern Language Journal, 81(4), 506-517. https://doi.org/10.1111/j.1540-4781.1997.tb05518.x

Quick, G., \& Siebörger, R. (2005). What matters in practice teaching? The perceptions of schools and students. South African Journal of Education, 25(1), 1-4.

Rajuan, M. (2008). Student teachers'perceptions of learning to teach as a basis for supervision of the mentoring relationship. Eindhoven University of Technology.

Robinson, K. (2015, April, 21). Interview with Ken Robinson (interview by Valerie Strauss for The Washington Post). https://doi.org/10.22233/20412495.0215.32

Smith, M. K. (2018). 'What is teaching?' in the encyclopaedia of informal education. Retrieved from December 22, 2019, from http://infed.org/mobi/what-is-teaching/

Wambugu, P., Barmao, A., \& Ng'eno, J. (2013). Student teachers' perceptions of teaching practice assessment in Egerton University, Kenya. Education Journal, 2(4), 169-175. https://doi.org/10.11648/j.edu.20130204.20

Williams-Pettway, M. L. (2005). Novice teachers'assessment of their teacher education programs. Unpublished doctoral dissertation. Auburn University, USA. 


\section{Appendix A}

\section{Survey for Internship Program (Practicum)}

Dear students,

This questionnaire is a part of a research study, and the purpose is to reveal your perceptions towards internship program (practicum). I kindly invite you to participate in this study by answering the questions correspondingly which will take about 5-10 minutes. Your identity will remain anonymous, and the data will be used just for the research purpose. You can withdraw your participation at any stage of the study without any circumstances. Your contribution is highly valuable. Thank you for your time.

\section{Part 1. Demographics}

Please circle your answers or complete the information as appropriate.

1. Your gender:

a. Female b. Male

2. Your age:

3. Type of the educational institution that you are doing your internship

a. State b. Private

4. At what level are you presently doing internship?
a. $\mathrm{KG} 1 / 2$
b. Primary School
c. Secondary School
d. High School

\section{Part 2. Knowledge, Skills and Dispositions}

Indicate the extent of your agreement by selecting and putting a tick $(\sqrt{ })$ in the table below. $(1=$ least $/ 5=$ most $)$

\begin{tabular}{llll}
\hline No & \multicolumn{1}{c}{\begin{tabular}{l} 
My internship programme provides me with a good foundation in English language teaching. \\
\hline 1
\end{tabular}} & & \\
2 & $\begin{array}{l}\text { My internship programme enables me to understand different language proficiency levels of } \\
\text { students and their different learning styles. }\end{array}$ \\
3 & $\begin{array}{l}\text { My internship programme stimulates critical thinking and problem solving in a particular } \\
\text { teaching context. }\end{array}$ \\
& $\begin{array}{l}\text { My internship programme helps me to learn a variety of teaching } \\
\text { strategies and how to adjust teaching methods in a lesson. }\end{array}$ \\
5 & $\begin{array}{l}\text { My internship programme teaches me a variety of assessment techniques and how to use them } \\
\text { effectively. }\end{array}$ \\
& My internship programme teaches me how to evaluate the effectiveness of my teaching.
\end{tabular}

\section{Part 3. Field Experiences and Practice Teaching}

Indicate the extent of your agreement by selecting and putting a tick $(\sqrt{ })$ in the table below. $(1=$ least $/ 5=$ most $)$

\begin{tabular}{|c|c|c|c|c|c|c|}
\hline No & & 1 & 2 & 3 & 4 & 5 \\
\hline 7 & $\begin{array}{l}\text { My practice teaching experience in a school setting provides me with opportunities to employ my } \\
\text { knowledge, skills, and dispositions with respect to different grade levels and student } \\
\text { characteristics. }\end{array}$ & & & & & \\
\hline 8 & $\begin{array}{l}\text { My practice teaching helps me to develop the competencies needed for a } \\
\text { teaching career. }\end{array}$ & & & & & \\
\hline 9 & My practice teaching provides opportunities to use technology in support of teaching and learning. & & & & & \\
\hline 10 & My mentor teacher is influential and resourceful in developing my career as a teacher. & & & & & \\
\hline 11 & My mentor teacher models the best teaching practices. & & & & & \\
\hline 12 & My university supervisor provides clear feedback and suggestions for improving my teaching. & & & & & \\
\hline 13 & My university supervisor has realistic expectations of me as a teacher in training. & & & & & \\
\hline 14 & $\begin{array}{l}\text { My university supervisor, mentor teacher, and I collaborate to evaluate } \\
\text { my performance during my practice teaching. }\end{array}$ & & & & & \\
\hline
\end{tabular}




\section{Part 4. Quality of Instruction}

Indicate the extent of your agreement by selecting and putting a tick $(\sqrt{ })$ in the table below. ( $1=$ least $/ 5=$ most)

\begin{tabular}{|c|c|c|c|c|c|c|}
\hline No & & 1 & 2 & 3 & 4 & 5 \\
\hline 15 & Instructors in my internship programme use appropriate instructional materials. & & & & & \\
\hline 16 & $\begin{array}{l}\text { Instructors in my internship programme model multiple teaching strategies that help all } \\
\text { students to learn. }\end{array}$ & & & & & \\
\hline 17 & $\begin{array}{l}\text { Instructors in my internship programme are enthusiastic when } \\
\text { presenting course content. }\end{array}$ & & & & & \\
\hline 18 & $\begin{array}{l}\text { Instructors in my internship programme show respect for students' } \\
\text { opinions. }\end{array}$ & & & & & \\
\hline 19 & $\begin{array}{l}\text { Instructors in my internship programme model oral and written communication skills } \\
\text { effectively. }\end{array}$ & & & & & \\
\hline
\end{tabular}

\section{Appendix B}

Open-ended questions

Your brief responses are much appreciated.

20. Identify three major strengths and weaknesses of your practice teaching programme.

21. Suggest two or more ways to strengthen your practice teaching programme.

\section{Copyrights}

Copyright for this article is retained by the author, with first publication rights granted to the journal.

This is an open-access article distributed under the terms and conditions of the Creative Commons Attribution license (http://creativecommons.org/licenses/by/4.0/). 